\title{
ANALISIS PERENCANAAN PENGELOLAAN DANA DESA (STUDI PADA DANA DESA TAHUN 2018 DI DESA BANGUNTAPAN, KECAMATAN BANGUNTAPAN, KABUPATEN BANTUL)
}

\author{
ANALYSIS OF VILLAGE FUND MANAGEMENT PLANNING \\ (STUDY OF 2018 VILLAGE FUNDS IN BANGUNTAPAN VILLAGE, KECAMATAN \\ BANGUNTAPAN, BANTUL DISTRICT)
}

\author{
Berlian Putri Maha Rini ${ }^{1}$, Rochmad Bayu Utomo ${ }^{2}$ \\ Universitas Mercu Buana Yogyakarta
}

\begin{abstract}
Abstrak
Penelitian ini bertujuan untuk mengetahui proses perencanaan pengelolaan dana desa tahun 2018 di Desa Banguntapan, kesesuaian antara perencanaan pengelolaan keuangan desa di Desa Banguntapan dengan Peraturan Menteri Dalam Negeri Nomor 113 Tahun 2014 tentang Pengelolaan Keuangan Desa, serta untuk mengetahui tantangan dan hambatan selama proses perencanaan pengelolaan dana desa di Desa Banguntapan, Kecamatan Banguntapan, Kabupaten Bantul. Penelitian ini menggunakan penelitian kualitatif. Teknik pengumpulan data dilakukan dengan wawancara, observasi dan dokumentasi. Peneliti melakukan uji keabsahan data dengan teknik triangulasi. Analisis data menggunakan analisis deskriptif evaluatif. Hasil penelitian ini menunjukkan bahwa proses perencanaan pengelolaan dana desa di Desa Banguntapan, Kecamatan Banguntapan, Kabupaten Bantul dimulai dari musdus untuk penyerapan aspirasi dan kebutuhan masyarakat, musrenbangdes untuk penyusunan RKPDes, musdes untuk sosialisasi RAPBDes dan pengajuan Perdes tentang APBDes ke Bupati melalui Camat. Melalui penjelasan tersebut, maka dapat disimpulkan bahwa perencanaan pengelolaan dana desa tahun 2018 sesuai dengan Peraturan Menteri Dalam Negeri Nomor 113 Tahun 2014. Sedangkan tantangan dan hambatan perencanaan pengelolaan dana desa terdiri dari penyesuaian perubahan peraturan, jumlah dana desa yang belum cukup, kualitas dan kuantitas SDM yang belum optimal, keterlambatan pencairan dana desa tahun 2018, minimnya respon masyarakat untuk program pemberdayaan serta sulit mendapatkan tenaga kerja untuk pembangunan fisik, terutama swakelola dan padat karya.
\end{abstract}

Kata Kunci: Dana desa, perencanaan pengelolaan dana desa, Peraturan Menteri Dalam Negeri Nomor 113 Tahun 2014

\begin{abstract}
This study aims to find out the process of village fund management planning in 2018 in Banguntapan Village, the suitability of village financial planning in Baanguntapan Village with the Minister of Home Affairs Regulation No. 113/2014 regarding Village Financial Management, and to know the challenges and obstacles during the process of village fund management planning in Banguntapan Village, Banguntapan District, Bantul Regency. This study uses qualitative research with case studies. Data collection techniques are done by interview, observation and documentation. Researchers conducted data validity tests with triangulation techniques. Data analysis uses evaluative descriptive analysis. The results of this study indicate that the village fund management planning process in Banguntapan Village, Banguntapan Subdistrict, Bantul Regency starts from the Musdus to encourage community aspirations and needs, musrenbangdes for the drafting of RKPDes, musdes for the socialization of RAPBDes and the submission of Perdes on APBDes to the Regent through the Camat. Through this explanation, it can be explained that the 2018 village fund planning is in accordance with the Minister of Home Affairs Regulation No. 113/2014. While challenges and obstacles in village fund management planning consist of adjusting regulatory changes, insufficient amount of village funds, inadequate quality and quantity of human resources, delays in disbursement of village funds in 2018, lack of community response to empowerment programs and difficulty in getting workers for physical development, especially self-management (swakelola) and labor-intensive (padat karya).
\end{abstract}

Keywords: Village funds, village fund management planning, Minister of Home Affairs Regulation No. $113 / 2014$ 


\section{PENDAHULUAN}

Otonomi daerah merupakan wujud pelaksanaan asas desentralisasi yang memberikan daerah wewenang untuk mengatur wilayah otonom masing-masing. Menurut Undang-Undang Nomor 23 Tahun 2014 tentang Pemerintahan Daerah Pasal 1 Ayat (6), disebutkan bahwa otonomi daerah adalah hak, wewenang, dan kewajiban daerah otonom untuk mengatur dan mengurus sendiri Urusan Pemerintahan dan kepentingan masyarakat setempat dalam sistem Negara Kesatuan Republik Indonesia. Hal ini menunjukkan bahwa daerah memiliki wewenang dalam melakukan pemberdayaan wilayah dan masyarakat, termasuk masyarakat desa guna menuju kesejahteraan bersama.

Kepentingan masyarakat tidak lepas dari kebutuhan yang dituangkan dalam aspirasi bersama. Aspirasi bersama inilah yang akan memengaruhi kreativitas, kualitas dan kemajuan sebuah desa. Hal ini juga diperkuat oleh pernyataan Menteri Keuangan Republik Indonesia, Sri Mulyani dalam sambutannya di kata pengantar Buku Pintar Dana Desa. Sri Mulyani menegaskan bahwa Desa adalah ujung tombak pembangunan dan peningkatan kesejahteraan masyarakat. Desa memiliki kesempatan untuk mengoptimalkan potensi alam, manusia dan ekonominya. Oleh karena itu, Desa diberikan kewenangan dan sumber dana yang memadai dari Pemerintah Pusat untuk mewujudkan kesejahteraan masyarakat. Salah satu sumber dana tersebut adalah Dana Desa.

Dana desa diberikan setiap tahun kepada setiap Desa untuk mewujudkan kesejahteraan masyarakatnya. Melalui dana desa, maka diharapkan desa dapat mengembangkan ekonomi, mengentaskan kemiskinan, meningkatkan kualitas kesehatan dan pendidikan, serta melahirkan inovasi dan kreasi untuk mewujudkan kebahagiaan bersama. Semua proses tersebut tidak lepas dari peran aktif masyarakat desa. Berdasarkan buku pintar dana desa (Kementerian Keuangan Republik Indonesia, 2017), penggunaan dana desa perlu diarahkan untuk mewujudkan kemandirian desa, mengacu pada sasaran pembangunan wilayah pedesaan dalam Rencana Pembangunan Jangka Menengah Nasional (RPJMN) 2015-2019. Hal ini menuntut Desa untuk mengelola dana desa sesuai dengan Peraturan Menteri Dalam Negeri Nomor 113 Tahun 2014 Pasal 1 Ayat (6) tentang Pengelolaan Keuangan Desa yang berbunyi, "pengelolaan keuangan desa adalah keseluruhan kegiatan yang meliputi perencanaan, pelaksanaan, penatausahaan, pelaporan, dan pertanggungjawaban keuangan desa".

Pengelolaan dana desa yang baik tidak terlepas dari proses perencanaan pengelolaan dana desa yang baik. Proses tersebut membutuhkan sumber daya manusia, dalam hal ini perangkat desa yang memahami proses perencanaan dan akuntansi secara optimal. Akuntansi pemerintahan berperan dalam mewujudkan tata kelola pemerintahan (good governance) yang baik, dimana akuntansi membantu perangkat desa dalam mencatat dan melaporkan semua program dan realisasi dana desa. Akuntansi pemerintahan memiliki tiga tujuan pokok yaitu pertanggungjawaban, manajerial dan pengawasan. Hal tersebut berkaitan dengan good governance yang menuntut adanya transparansi dan akuntabilitas atas kinerja perangkat desa.

Kabupaten Bantul merupakan salah satu Pemerintah Daerah yang mendapatkan dana desa dari APBN untuk disalurkan ke desa-desa di Kabupaten Bantul. Pengelolaan Dana Desa Kabupaten Bantul diatur dalam Peraturan Bupati Bantul Nomor 88 Tahun 2016 tentang Pengelolaan Keuangan Desa. Pengelolaan Keuangan Desa diatur dalam BAB V Pengelolaan yang terdiri dari perencanaan, penatausahaan penerimaan desa, penatausahaan pengeluaran desa, pelaporan, perubahan APBDesa dan pertanggungjawaban. Berdasarkan rincian Alokasi Dana Desa Provinsi/Kabupaten/Kota dalam APBN T.A. 2019, Kabupaten Bantul menerima dana desa sebesar Rp98.359.905.000,00. Gambar 1.2. memberikan gambaran terkait Alokasi Dana Desa Provinsi D.I. Yogyakarta Tahun Anggaran 2019. 


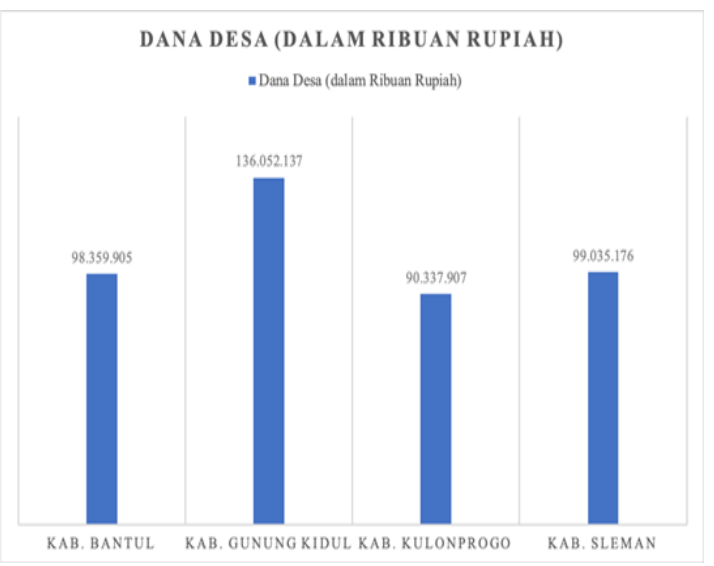

Gambar 1. Alokasi Dana Desa Provinsi D.I. Yogyakarta T.A. 2019

Sumber : http://www.djpk.kemenkeu.go.id/

Desa Banguntapan merupakan salah satu desa yang ada di Kabupaten Bantul yang menerima dana desa. Berdasarkan data dari Peraturan Bupati Bantul No. 29 Tahun 2018 tentang Tata Cara Pengalokasian Dana Desa dan Besaran Alokasi Dana Desa untuk Setiap Tahun Anggaran 2018, Desa Banguntapan memiliki Pagu Desa sebesar Rp1.778.370.000,00. Pada tahun 2018, Desa Banguntapan mendapat peringkat ke-12 kategori Indeks Desa Membangun (IDM) dari 100 desa terbaik di Indonesia oleh Kementerian Desa, Pembangunan Daerah Tertinggal dan dan Transmigrasi (Kemendes PDTT) (Bengkulu Post, 2018). Prestasi tersebut tentu tidak lepas dari perencanaan dan pengelolaan dana desa yang baik agar peningkatan ekonomi dan kesejahteraan masyarakat maksimal. Hal ini menjadi salah satu topik penelitian yang menarik bagi peneliti, dimana dengan mengetahui proses perencanaan pengelolaan dana desa di Desa Banguntapan, maka diharapkan dapat menjadi contoh dan sarana study banding desa yang lainnya.

Menurut hasil penelitian dari Sofyani, Hafiez dan Rudi Suryanto, Sigit Arie Wibowo, Harjanti Widiastuti (2018) tentang praktik pengelolaan dan tata kelola Pemerintahan di Desa Dlingo Kabupaten Bantul menunjukkan bahwa permasalahan yang terjadi di pemerintahan desa dibagi menjadi 3 sub bab utama yaitu (1) masalah perumusan rencana strategis, (2) masalah pelaporan keuangan dan kinerja, (3) masalah pencapaian kinerja desa. Hasil penelitian lainnya berasal dari Triani, Ni Nyoman Alit dan Susi Handayani (2018) menemukan bahwa pengelolaan keuangan desa di Desa Plosogeneng, Kecamatan Jombang, Kabupaten Jombang; Desa Donowarih, Kecamatan Karangploso, Kabupaten Malang; dan Desa Pesantren, Kecamatan Tembelang, Kabupaten Jombang secara umum telah sesuai dengan peraturan yang berlaku. Meskipun masih ditemukan kendala dalam pengelolaan keuangan desa yang disebabkan oleh perubahan Kementerian dan kemampuan penyalur dana desa yang masih belum mumpuni, sehingga menghambat penyaluran dana desa. Shuha (2018) menyatakan bahwa perencanaan pengelolaan dana desa di Kecamatan Lubuk Alung, Kabupaten Padang Pariaman telah sesuai dengan Peraturan Menteri Dalam Negeri Nomor 113 Tahun 2014 tentang Pengelolaan Keuangan Desa. Sedangkan pelaksanaan, penatausahaan, pelaporan dan pertanggungjawaban tidak sesuai dengan Peraturan Menteri Dalam Negeri Nomor 113 Tahun 2014 tentang Pengelolaan Keuangan Desa. Faktor penghambat dalam pengelolaan dana desa di Kecamatan Lubuk Alung berupa sumber daya manusia, keterlambatan pelaporan, perubahan APBDes, internet dan pemahaman masyarakat. Sedangkan menurut hasil penelitian Purnamasari (2016), menunjukkan bahwa perencanaan pengelolaan alokasi dana desa di Kecamatan Jabon, Kabupaten Sidoarjo sudah cukup baik, dibuktikan dengan prosedur dalam tahap perencanaan telah mengikuti aturan yang berlaku yaitu dengan mengadakan musyawarah desa yang melibatkan semua perangkat desa, Badan Permusyawaratan Desa (BPD) dan masyarakat. Dalam proses penggunaan Alokasi Dana Desa juga telah sesuai dengan peraturan yang berlaku, dibuktikan dengan penggunaan disesuaikan dengan Rencana Kerja Pemerintah Desa (RKPDes) dan Rencana Pembangunan Jangka Menengah Desa (RPJMDes). Sedangkan dalam tahap pertanggungjawaban, hampir semua desa mengalami 
keterlambatan yang diakibatkan karena keterlambatan pencairan Alokasi Dana Desa di awal periode dan SDM yang kurang memahami.

Berdasarkan latar belakang yang telah diuraikan diatas, peneliti tertarik untuk melakukan penelitian proses perencanaan pengelolaan dana desa tahun 2018 di Desa Banguntapan, kesesuaian antara perencanaan pengelolaan keuangan desa di Desa Banguntapan dengan Peraturan Menteri Dalam Negeri Nomor 113 Tahun 2014 tentang Pengelolaan Keuangan Desa, serta untuk mengetahui tantangan dan hambatan selama proses perencanaan pengelolaan dana desa di Desa Banguntapan, Kecamatan Banguntapan, Kabupaten Bantul.

\section{METODE}

Penelitian ini merupakan jenis penelitian kualitatif dengan metode analisis deskriptif evaluatif, dimana peneliti lebih memusatkan pada deskripsi data yang berupa kalimat pernyataan dari informan dan perilaku yang diamati. Berdasarkan pengertian diatas, dapat disimpulkan bahwa penelitian ini menggunakan penelitian kualitatif dengan analisis deskriptif untuk menggambarkan keadaan di lapangan secara sistematis melalui fakta-fakta dengan interpretasi yang tepat, sehingga dapat memahami tentang perencanaan dan pengelolaan dana desa di Desa Banguntapan, Kecamatan Bangutapan, Kabupaten Bantul. Metode analisis deskriptif evaluatif digunakan untuk membandingkan penerapan di lapangan dengan Peraturan Menteri Dalam Negeri Nomor 113 Tahun 2014.

\section{Subjek Penelitian}

Subjek dalam penelitian ini adalah informan yang dapat memberikan informasi dan data dalam penelitian. Subjek tersebut meliputi:

Kepala Desa Banguntapan sebagai pemegang kekuasaan pengelolaan keuangan desa; Sekretaris Desa Banguntapan yang membantu Kepala Desa dalam mengelola keuangan desa; Bendahara Desa Banguntapan sebagai penatausahaan pengelolaan keuangan desa; Badan Permusyawaratan Desa (BPD) Desa Banguntapan sebagai pengawas kinerja Pemerintah Desa.

\section{Jenis dan Sumber Data}

Penelitian ini menggunakan dua sumber data yaitu: Data Primer (Data primer dalam penelitian ini berupa hasil wawancara dan hasil observasi di lapangan yang diperoleh melalui wawancara dengan perangkat desa di Desa Banguntapan) serta Data Sekunder (Data sekunder dalam penelitian ini dapat berupa RPJM Desa, RKP Desa, penelitian terdahulu, serta dokumendokumen terkait dana desa).

\section{Teknik Pengumpulan Data}

Penelitian ini menggunakan teknik pengumpulan data dengan menggunakan metode sebagai berikut: Wawancara (Dalam penelitian ini wawancara dilakukan secara langsung dengan informan, mengenai proses perencanaan pengelolaan dana desa, kesesuaian perencanaan pengelolaan dana desa dengan Peraturan Menteri Dalam Negeri Nomor 113 Tahun 2014, tantangan dan hambatan yang ditemui dalam melakukan perencanaan dan pengelolaan dana desa di Desa Banguntapan), dan Dokumentasi (Penelitian ini menggunakan dokumentasi berupa data-data tentang dana desa, foto, laporan kegiatan, serta segala bentuk dokumentasi yang merekam wawancara antara peneliti dengan perangkat desa).

\section{Teknik Sampling}

Pada penelitian ini, peneliti menggunakan teknik purposive sampling dan snowball sampling, sehingga saat di lapangan peneliti mengumpulkan data dari satu narasumber ke narasumber lain melalui wawancara mendalam dan akan berhenti saat tidak ditemukan informasi baru, hasil wawancara menunjukkan replikasi sehingga pada saat itu terjadi momen titik jenuh informasi. 


\section{Instrumen Penelitian}

Instrumen penelitian dalam penelitian kualitatif adalah peneliti itu sendiri. Wawancara mendalam dan dokumentasi akan berfokus pada 3 hal sebagai berikut: Proses perencanaan pengelolaan dana desa tahun 2018 di Desa Banguntapan, Kecamatan Banguntapan, Kabupaten Bantul, Kesesuaian perencanaan pengelolaan dana desa di Desa Banguntapan dengan Peraturan Menteri Dalam Negeri Nomor 113 Tahun 2014 tentang Pengelolaan Keuangan Desa, dan Tantangan dan hambatan selama proses perencanaan pengelolaan dana desa di Desa Banguntapan, Kecamatan Banguntapan, Kabupaten Bantul.

\section{Uji Keabsahan Data}

Penelitian ini menggunakan teknik triangulasi sebagai alat ukur untuk menguji keabsahan data. Teknik triangulasi dapat dilakukan dengan cara mengecek ulang atau membandingkan data yang diperoleh dengan waktu atau alat yang berbeda. Tahapan yang dapat dilakukan untuk melakukan triangulasi berupa: 1. Membandingkan data hasil wawancara dari perangkat desa dengan masyarakat sekitar, dan 2. Membandingkan data hasil wawancara dengan data sekunder penelitian.

\section{Teknik Analisis Data}

Teknik analisis data yang digunakan dalam penelitian ini mengacu pada 3 (tiga) langkah. 1. Data Reduction (Reduksi Data), 2. Data Display (Penyajian Data) dan 3. Drawing Conclusions (Penarikan Kesimpulan)

\section{HASIL DAN PEMBAHASAN \\ Hasil}

Tabel 1. Hasil Analisis Tahapan Perencanaan Pengelolaan Dana Desa di Desa Banguntapan

\begin{tabular}{|l|l|l|}
\hline Tahapan & Pemeran & Analisis \\
\hline $\begin{array}{l}\text { Musyawarah } \\
\text { (musdus) }\end{array}$ & $\begin{array}{l}\text { Kepala } \\
\text { dusun, } \\
\text { masyarakat, } \\
\text { Pemerintah } \\
\text { Desa dan } \\
\text { BPD }\end{array}$ & $\begin{array}{l}\text { BPD } \\
\text { memfasilitasi untuk } \\
\text { menyerap aspirasi } \\
\text { dan kebutuhan } \\
\text { masyarakat. } \\
\text { Segala kebutuhan } \\
\text { terkait musdus } \\
\text { mulai dari } \\
\text { undangan, dan } \\
\text { konsumsi didukung } \\
\text { lainnya derintah } \\
\text { oleh Pemerintah } \\
\text { Desa. }\end{array}$ \\
\hline $\begin{array}{l}\text { Musrenbang } \\
\text { Desa }\end{array}$ & $\begin{array}{l}\text { Tim } \\
\text { penyusun } \\
\text { RKP, BPD, } \\
\text { masyarakat }\end{array}$ & $\begin{array}{l}\text { Musrenbangdes } \\
\text { dilakukan untuk } \\
\text { menyusun Keran } \\
\text { Rencana Kerja } \\
\text { Pemerintah Desa } \\
\text { (RKPDes yang } \\
\text { berpedoman pada } \\
\text { kebutuhan } \\
\text { masyarakat dan } \\
\text { RPJMDes. }\end{array}$ \\
\hline
\end{tabular}




\begin{tabular}{|c|c|c|}
\hline Musdes & $\begin{array}{l}\text { Pemerintah } \\
\text { Desa, BPD, } \\
\text { masyarakat }\end{array}$ & $\begin{array}{l}\text { Musdes digelar } \\
\text { untuk } \\
\text { memberikan } \\
\text { sosialisasi kepada } \\
\text { masyarakat atas } \\
\text { Rancangan } \\
\text { Anggaran } \\
\text { Pendapatan dan } \\
\text { Belanja Desa } \\
\text { (RAPBDes), } \\
\text { dalam musdes } \\
\text { para Kas dan } \\
\text { Kaur memberikan } \\
\text { penjelasan tentang } \\
\text { urgensi program } \\
\text { kerja yang } \\
\text { dianggarkan } \\
\text { dalam APBDes. }\end{array}$ \\
\hline $\begin{array}{l}\text { Penyusunan } \\
\text { Raperdes } \\
\text { tentang } \\
\text { APBDes }\end{array}$ & $\begin{array}{l}\text { Sekretaris } \\
\text { Desa, } \\
\text { Kepala } \\
\text { Desa dan } \\
\text { BPD }\end{array}$ & $\begin{array}{l}\text { Sekretaris } \\
\text { menyusun } \\
\text { Rencana } \\
\text { Peraturan Desa } \\
\text { tentang APBDes } \\
\text { dan mengajukan } \\
\text { ke Kepala Desa } \\
\text { untuk dicermati. } \\
\text { Setelah r itu, } \\
\text { Kepala Desa } \\
\text { menyampaikan } \\
\text { Raperdes tentang } \\
\text { APBDes ke BPD } \\
\text { untuk dicermati } \\
\text { dan dibahas } \\
\text { bersama. }\end{array}$ \\
\hline $\begin{array}{l}\text { Pengajuan } \\
\text { Raperdes } \\
\text { tentang } \\
\text { APBDes ke } \\
\text { Bupati } \\
\text { melalui Camat }\end{array}$ & $\begin{array}{l}\text { Pemerintah } \\
\text { Desa, } \\
\text { Camat }\end{array}$ & $\begin{array}{lr}\text { Camat melakukan } \\
\text { evaluasi atas } \\
\text { Raperdes tentang } \\
\text { APBDes dalam } \\
\text { jangka waktu } 20 \\
\text { (dua puluh) hari. }\end{array}$ \\
\hline $\begin{array}{l}\text { Camat } \\
\text { mengeluarkan } \\
\text { rekomendasi } \\
\text { tentang } \\
\text { Raperdes ke } \\
\text { Bupati }\end{array}$ & $\begin{array}{l}\text { Camat, } \\
\text { Bupati }\end{array}$ & $\begin{array}{lr}\text { Camat } & \\
\text { mengeluarkan } & \\
\text { rekomendasi } & \text { atas } \\
\text { Raperdes } & \text { tentang } \\
\text { APBDes } & \text { ke } \\
\text { Bupati. }\end{array}$ \\
\hline
\end{tabular}




\section{Pembahasan}

Proses Perencanaan Pengelolaan Dana Desa Tahun 2018 Di Desa Banguntapan, Kecamatan Banguntapan, Kabupaten Bantul

Perencanaan dana desa tahun 2018 mulai dilakukan pada bulan Juni tahun 2017. BPD Desa Banguntapan yang terdiri dari perwakilan setiap dusun akan menggelar musyawarah dusun (musdus) di setiap dusun untuk menyerap aspirasi dan kebutuhan masyarakat. Segala kebutuhan musdus difasilitasi oleh Pemerintah Desa, mulai dari pembuatan undangan hingga konsumsi musdus. Musdus dihadiri oleh Kepala Dusun, masyarakat, BPD, dan Pamong/Pemerintah Desa. Setelah musdus dilaksanakan, Pemerintah Desa memiliki daftar aspirasi dan mulai menentukan skala prioritas untuk dikerjakan.

Skala prioritas tersebut menjadi salah satu acuan dalam penyusunan Rencana Kerja Pembangunan Desa (RKPDes). RKPDes disusun oleh tim penyusun RKPDes yang terdiri dari Sekretaris Desa sebagai Ketua, Ketua LPMD sebagai sekretaris, tokoh masyarakat yang mencakup unsur perempuan. Setelah itu, Pemerintah Desa menggelar musyawarah pembangunan desa (musrenbangdes) dan mengundang masyarakat untuk melakukan musyawarah RKPDes.

Setelah tahapan tersebut selesai, maka Pemerintah Desa mulai menyusun Rancangan Anggaran Pendapatan dan Belanja Desa (RAPBDes) sesuai dengan pagu indikatif yang telah disosialisasikan Bupati. Dalam rangka mewujudkan asas pengelolaan keuangan desa transparan dan partisipatif, Pemerintah Desa akan menggelar musyawarah desa (musdes) untuk mensosialisasikan tentang RAPBDes. Musdes dihadiri oleh masyarakat, BPD, Pemerintah Desa termasuk Kasi dan Kaur. Kasi dan Kaur memberikan penjelasan tentang urgensi setiap program kerja yang dianggarkan dalam RAPBDes.

Tahapan selanjutnya dalam perencanaan pengelolaan dana desa adalah penyusunan Rancangan Peraturan Desa tentang APBDes. Rancangan Peraturan Desa tentang APBDes disusun oleh Sekretaris Desa dan diajukan ke Kepala Desa untuk dicermati. Setelah itu, Kepala Desa memberikan Rancangan Peraturan Desa tentang APBDes kepada Badan Permusyawaratan Desa (BPD) untuk dicermati, dibahas dan disepakati bersama. Rancangan Peraturan Desa tentang APBDes disepakati bersama paling lambat bulan Oktober tahun 2017.

Rancangan Peraturan Desa tentang APBDes yang telah disepakati diusulkan ke Bupati melalui Camat. Camat akan mengevaluasi dalam jangka waktu maksimal 20 (dua puluh) hari. Jika terdapat evaluasi, maka Pemerintah Desa wajib melakukan perbaikan dan mengirimkan kembali ke Camat. Setelah proses evaluasi selesai, maka Camat akan memberikan rekomendasi tentang Rancangan Peraturan Desa tentang APBDes kepada Bupati untuk diproses lebih lanjut. Bupati akan menetapkan Rancangan Peraturan Desa tentang APBDes menjadi Peraturan Desa tentang APBDes dalam jangka waktu maksimal 20 (dua puluh) hari.

Peraturan Desa tentang APBDes yang telah ditetapkan menjadi awal Pemerintah Desa untuk mengelola dana desa, mulai dari pelaksanaan, penatausahaan, pelaporan dan pertanggungjawaban.

\section{Analisis Perencanaan Pengelolaan Dana Desa di Desa Banguntapan dengan Peraturan Menteri Dalam Negeri Nomor 113 Tahun 2014 tentang Pengelolaan Keuangan Desa}

Perencanaan pengelolaan dana desa merupakan proses panjang yang mulai dilakukan pada bulan Juni hingga bulan September tahun berjalan, dalam hal ini tahun 2017. Pada dasarnya, perencanaan pengelolaan dana desa sama dengan perencanaan pengelolaan pendapatan desa lainnya, dimana hal tersebut diatur dalam Peraturan Menteri Dalam Negeri Nomor 113 Tahun 2014 tentang Pengelolaan Keuangan Desa.

Perbedaan dana desa dengan pendapatan desa lainnya adalah pada pelaksanaan yang diatur lebih spesifik dengan dua prioritas, yaitu pembangunan desa dan pemberdayaan masyarakat sesuai dengan Peraturan Menteri Desa, Pembangunan Daerah Tertinggal, dan Transmigrasi Republik Indonesia Nomor 19 Tahun 2017 tentang Prioritas Penggunaan Dana Desa Tahun Anggaran 2018.

Penelitian ini berfokus pada tahap perencanaan pengelolaan dana desa, dimana proses tersebut telah dijelaskan pada sub bab analisis data dan poin C.1 pembahasan. Berdasarkan hal tersebut, peneliti melakukan evaluasi perbandingan antara proses yang dilaksanakan Pemerintah Desa Banguntapan dengan Peraturan Menteri Dalam Negeri Nomor 113 Tahun 2014. Adapun perbandingan tersebut ditampilkan dalam tabel 2 . 
Tabel 2. Perbandingan Proses Perencanaan Dana Desa dengan Permendagri Nomor 113 Tahun

\begin{tabular}{|c|c|c|c|c|}
\hline $\begin{array}{l}\text { Aktivita } \\
\mathrm{s}\end{array}$ & $\begin{array}{l}\text { Pemerintah } \\
\text { Desa } \\
\text { Banguntapa } \\
\mathrm{n}\end{array}$ & \begin{tabular}{|ll|}
\multicolumn{2}{l}{ Permendagri } \\
No. $\quad 113$ \\
Tahun & 2014
\end{tabular} & $\begin{array}{l}S \\
S\end{array}$ & $\begin{array}{l}\mathrm{T} \\
\mathrm{T} \\
\mathrm{S}\end{array}$ \\
\hline $\begin{array}{l}\text { Penyusu } \\
\text { nan } \\
\text { Raperde } \\
\text { s tentang } \\
\text { APBDes }\end{array}$ & $\begin{array}{l}\text { Sekretaris } \\
\text { Desa } \\
\text { menyusun } \\
\text { Raperdes } \\
\text { tentang } \\
\text { APBDes } \\
\text { berdasarkan } \\
\text { hasil } \\
\text { musrenbang } \\
\text { des. }\end{array}$ & \begin{tabular}{|l|} 
Sekretaris \\
Desa \\
menyusun \\
Rancangan \\
Peraturan \\
Desa tentang \\
APBDesa \\
berdasarkan \\
RKPDesa \\
tahun \\
berkenaan
\end{tabular} & $\checkmark$ & - \\
\hline $\begin{array}{l}\text { Pembah } \\
\text { asan } \\
\text { Raperde } \\
\text { s tentang } \\
\text { APBDes }\end{array}$ & $\begin{array}{l}\text { Pemerintah } \\
\text { Desa } \\
\text { melakukan } \\
\text { pembahasa } \\
\mathrm{n} \text { Raperdes } \\
\text { tentang } \\
\text { APBDes } \\
\text { bersama } \\
\text { BPD }\end{array}$ & \begin{tabular}{|l|} 
Rancangan \\
peraturan \\
Desa tentang \\
APBDesa \\
sebagaimana \\
dimaksud \\
pada ayat (2) \\
disampaikan \\
oleh Kepala \\
Desa kepada \\
Badan \\
Permusyawar \\
atan Desa \\
untuk \\
dibahas dan \\
disepakati \\
bersama
\end{tabular} & $\checkmark$ & - \\
\hline $\begin{array}{l}\text { Raperde } \\
\text { s tentang } \\
\text { APBDes } \\
\text { disampa } \\
\text { ikan ke } \\
\text { Bupati } \\
\text { melalui } \\
\text { Camat }\end{array}$ & $\begin{array}{l}\text { Pemerintah } \\
\text { Desa } \\
\text { menyampai } \\
\text { kan } \\
\text { Raperdes } \\
\text { tentang } \\
\text { APBDes } \\
\text { kepada } \\
\text { Bupati } \\
\text { melalui } \\
\text { Camat } \\
\text { untuk } \\
\text { dievaluasi }\end{array}$ & \begin{tabular}{|l} 
Rancangan \\
Peraturan \\
Desa tentang \\
APBDesa \\
yang telah \\
disepakati \\
bersama \\
sebagaimana \\
dimaksud \\
dalam Pasal \\
20 ayat (3) \\
disampaikan \\
oleh Kepala \\
Desa kepada \\
Bupati/Walik \\
ota melalui
\end{tabular} & $\sqrt{ }$ & - \\
\hline
\end{tabular}




\begin{tabular}{|c|c|c|c|}
\hline & & $\begin{array}{l}\text { camat atau } \\
\text { sebutan lain } \\
\text { paling lambat } \\
3 \text { (tiga) hari } \\
\text { sejak } \\
\text { disepakati } \\
\text { untuk } \\
\text { dievaluasi }\end{array}$ & \\
\hline $\begin{array}{l}\text { Penetap } \\
\text { an } \\
\text { Raperde } \\
\text { s tentang } \\
\text { APBDes } \\
\text { menjadi } \\
\text { Perdes } \\
\text { tentang } \\
\text { APBDes }\end{array}$ & $\begin{array}{l}\text { Camat } \\
\text { melakukan } \\
\text { evaluasi } \\
\text { terhadap } \\
\text { Raperdes } \\
\text { tentang } \\
\text { APBDes } \\
\text { dalam } \\
\text { jangka } \\
\text { waktu } 20 \\
\text { hari. Jika } \\
\text { tidak } \\
\text { terdapat } \\
\text { evaluasi, } \\
\text { Camat akan } \\
\text { mengeluark } \\
\text { an } \\
\text { rekomendas } \\
\text { i kepada } \\
\text { Bupati } \\
\text { untuk } \\
\text { menetapkan } \\
\text { Raperdes } \\
\text { tentang } \\
\text { APBDes } \\
\text { yang } \\
\text { diusulkan }\end{array}$ & $\begin{array}{l}\text { Bupati/Walik } \\
\text { ota } \\
\text { menetapkan } \\
\text { hasil evaluasi } \\
\text { Rancangan } \\
\text { APBDesa } \\
\text { sebagaimana } \\
\text { dimaksud } \\
\text { pada ayat (1) } \\
\text { paling lama } \\
20 \quad \text { dua } \\
\text { puluh) hari } \\
\text { kerja sejak } \\
\text { diterimanya } \\
\text { Rancangan } \\
\text { Peraturan } \\
\text { Desa tentang } \\
\text { APBDesa. }\end{array}$ & $\lambda$ \\
\hline
\end{tabular}

Tantangan dan Hambatan Selama Proses Perencanaan Pengelolan Dana Desa di Desa Banguntapan Kecamatan Banguntapan, Kabupaten Bantul

Perencanaan pengelolaan Dana Desa merupakan hal penting yang wajib dilaksanakan agar pelaksanaan penggunaan dana desa dapat diukur dengan indikator yang tepat. Pada dasarnya, Dana Desa ditujukan untuk 2 (dua) program prioritas yaitu pelaksanaan pembangunan dan pemberdayaan masyarakat. Semua program prioritas tersebut mempunyai tujuan akhir pada peningkatan taraf hidup masyarakat, menumbuhkan ekonomi desa dan mengentaskan kemiskinan. Berdasarkan hal tersebut, peneliti menganalisis tantangan dan hambatan selama proses perencanaan pengelolaan dana desa di Desa Banguntapan, Kecamatan Banguntapan, Kabupaten Bantul sebagai berikut:

\section{Penyesuaian atas Perubahan Peraturan yang Berlaku}

Peraturan tentang pengelolaan keuangan desa telah mengalami perubahan dari Peraturan Menteri Dalam Negeri Nomor 113 Tahun 2014 ke Peraturan Menteri Dalam Negeri Nomor 20 Tahun 2018. Hal ini secara otomatis akan berdampak pada Peraturan dibawahnya, seperti Peraturan Bupati Bantul Nomor 88 Tahun 2016 tentang Pengelolaan Keuangan Desa berubah menjadi 
Peraturan Bupati Bantul Nomor 131 Tahun 2018 tentang Pengelolaan Keuangan Desa. Perubahan tersebut menuntut Pemerintah Desa untuk melakukan penyesuaian atas peraturan yang berlaku.

\section{Dana Desa Belum Mencukupi Kebutuhan Desa Secara Keseluruhan}

Berdasarkan hasil penelitian, Dana Desa yang diterima Desa Banguntapan belum bisa mencukupi kebutuhan desa secara keseluruhan. Hal ini disebabkan karena beberapa faktor diantaranya wilayah desa yang luas, penduduk yang banyak dan wilayah sebagai penyangga kota, sehingga mengakibatkan perbedaan upah pekerja yang berbeda dibanding desa lainnya. Hal ini tentu mempengaruhi pelaksanaan program kerja yang telah ditetapkan di RKPDes.

\section{Kualitas dan Kuantitas Sumber Daya Manusia Belum Optimal}

Dana Desa memberikan tantangan kepada Pemerintah Desa untuk terus aktif melaksanakan program prioritas yaitu pembangunan dan pemberdayaan masyarakat. Guna mencapai hasil yang optimal, tentu dibutuhkan Sumber Daya Manusia (SDM) yang berkualitas baik dari sisi keahlian dan kecepatan bekerja, serta kuantitas yang memadai. Berdasarkan hasil penelitian, kuantitas dan kualitas SDM yang belum optimal menjadi tantangan dan hambatan dalam melaksanakan perencanaan pengelolaan dana desa.

\section{Pencairan Dana Desa Terlambat}

Pada tahun 2018, pencairan dana desa terlambat dan baru turun di bulan Mei 2018. Hal ini disebabkan oleh adanya desa tanggung renteng, dimana dana desa tidak akan turun sebelum desa lain menyelesaikan proses administrasinya. Keterlambatan pencairan dana desa berdampak pada pelaksanaan program kerja tidak sesuai jadwal, sehingga hal ini menyebabkan adanya sisa dana desa karena sudah berganti ke tahun anggaran berikutnya.

\section{Minimnya Respon Masyarakat untuk Program Pemberdayaan}

Dana desa diperuntukkan untuk pembangunan dan pemberdayaan masyarakat. Dalam pelaksanaannya, aspirasi masyarakat yang menyangkut pemberdayaan sedikit, sehingga berakibat pada program pemberdayaan masyarakat berjumlah lebih sedikit dibanding program pembangunan.

\section{Sulit Mendapatkan Tenaga Kerja untuk Pembangunan Fisik, Terutama Swakelola dan Padat Karya}

Salah satu prioritas dana desa adalah pembangunan. Dalam rangka mengentaskan kemiskinan, maka dana desa mewajibkan adanya swakelola dan padat karya, dimana tenaga kerja untuk pembangunan fisik menggunakan tenaga kerja lokal yang salah satu syaratnya memiliki KK miskin. Namun, hal tersebut menjadi hambatan di Desa Banguntapan karena tenaga kerja yang memiliki KK miskin belum tentu memiliki keahlian pertukangan, dan ditambah lagi dengan kondisi sebagai penyangga perkotaan maka upah pekerja lebih tinggi dibanding desa lain.

\section{KESIMPULAN \\ Kesimpulan}

Berdasarkan hasil penelitian dan pembahasan yang telah dikemukakan sebelumnya, maka peneliti dapat menyimpulkan sebagai berikut:

Proses perencanaan pengelolaan dana desa tahun 2018 di Desa Banguntapan, Kecamatan Banguntapan, Kabupaten Bantul dimulai dari musyawarah dusun (musdus), musrenbangdes, musdes hingga penetapan Perdes tentang APBDes oleh Bupati Bantul.

Perencanaan pengelolaan keuangan desa di Desa Banguntapan sesuai dengan Peraturan Menteri Dalam Negeri Nomor 113 Tahun 2014 tentang Pengelolaan Keuangan Desa.

Tantangan dan hambatan pada proses perencanaan pengelolaan dana desa di Desa Banguntapan berasal dari faktor internal dan eksternal, diantaranya SDM; dana desa yang kurang; pencairan dana desa terlambat; perubahan peraturan; minimnya respon masyarakat untuk program pemberdayaan; dan kesulitan mencari tenaga kerja untuk program swakelola atau padat karya. 


\section{Saran}

Berdasarkan hasil penelitian yang telah dilakukan, maka saran untuk peneliti selanjutnya adalah memperluas topik penelitian pengelolaan dana desa mulai dari proses perencanaan sampai proses pertanggungjawaban dengan salah satu sumbernya berasal dari transkrip wawancara dalam penelitian ini. Sehingga peneliti selanjutnya dapat melakukan penelitian lebih mendalam terhadap pengelolaan dana desa dengan tambahan melibatkan masyarakat sebagai informan untuk memperkuat penelitian dan keabsahan data.

\section{DAFTAR PUSTAKA}

Alfindasari, Dessy. "Teknik Sampling Pada Penelitian Kualitatif". https://www.eurekapendidikan.com/2014/11/teknik-sampling-pada-penelitian.html. Diakses pada tanggal 26 April 2019 pukul 11.18 WIB.

Badan Pengawasan Keuangan dan Pembangunan (BPKP). 2015. "Petunjuk Pelaksanaan Bimbingan Kan Konsultasi Pengelolaan Keuangan Desa”. http://www.bpkp.go.id/public/upload/unit/sakd/files/Juklakbimkonkeudesa.pdf. Diakses pada tanggal 03 Maret 2019 pukul 21.46 WIB.

Hutami, Adi Siti. 2017. “Analisis Pengelolaan Alokasi Dana Desa (ADD)”. Skripsi.

Kementerian Keuangan Republik Indonesia. ABPN 2019. https://www.kemenkeu.go.id/apbn2019. Diakses pada tanggal 20 Maret 2019 pukul 22.26 WIB.

Kementerian Keuangan Republik Indonesia. Buku Pintar Dana Desa. https://www.kemenkeu.go.id/media/6749/buku-pintar-dana-desa.pdf. Diakses pada tanggal 20 Maret 2019 pukul 22.28 WIB.

Langkun, Pretty A., Ventje I., dan Rudy J.P. 2019. "Analisis Penyaluran dan Penggunaan Dana Desa di Desa Linelean Kecamatan Modoinding Kabupaten Minahasa Selatan”. Jurnal Riset Akuntansi Going Concern 14 (1) Hal. 54-57.

Manto, Hisbul dan Abd. Qodir Djaelani. 2017. "Analisis Perencanaan Pengelolaan Keuangan Desa (Studi Pada Desa Trapang Kecamatan Banyuates Kabupaten Sampang)”. e-Jurnal Riset Manajemen Fakultas Ekonomi Unisma.

Mutamimmah, Munfarida R., Alwan Sri K., Rochman E. 2018. "Pengelolaan Keuangan Desa melalui e-Village Budgeting di Kabupaten Banyuwangi". e-Journal Ekonomi Bisnis dan Akuntansi Vol. 1 Hal. 105-108.

Nazir, Mohammad. 2011. "Metode Penelitian”. Cetakan 6. Bogor: Ghalia Indonesia.

Peraturan Bupati Bantul No. 29 Tahun 2018 tentang Tata Cara Pengalokasian Dana Desa dan Besaran Alokasi Dana Desa untuk Setiap Tahun Anggaran 2018.

Peraturan Bupati Bantul Nomor 88 Tahun 2016 tentang Pengelolaan Keuangan Desa.

Peraturan Menteri Dalam Negeri Nomor 113 Tahun 2014 tentang Pengelolaan Keuangan Desa.

Peraturan Menteri Dalam Negeri Republik Indonesia Nomor 20 Tahun 2018 Tentang Pengelolaan Keuangan Desa.

Peraturan Menteri Desa, Pembangunan Daerah Tertinggal, dan Transmigrasi Republik Indonesia Nomor 19 Tahun 2017 tentang Prioritas Penggunaan Dana Desa Tahun Anggaran 2018. 
Peraturan Pemerintah Republik Indonesia Nomor 43 Tahun 2014 tentang Peraturan Pelaksanaan Undang-Undang Nomor 6 Tahun 2014 Tentang Desa.

Purnamasari, Desy. 2016. “Analisis Pengelolaan Alokasi Dana Desa (ADD) di Kecamatan Jabon Kabupaten Sidoarjo Tahun 2015”. Skripsi.

Rincian Alokasi Dana Desa Provinsi/Kabupaten/Kota dalam APBN T.A. 2019.

http://www.djpk.kemenkeu.go.id/wpcontent/uploads/2018/10/DANA-DESA.pdf. Diakses pada tanggal 20 Maret 2019 pukul 23.06 WIB.

Satria, Adjie. 2018. Kota Bani Urutan ke-6 Desa Terbaik Se-Indonesia, Berikut Daftarnya.http://www.bengkulupost.co.id/2018/12/01/kota-bani urutan-ke-6-desa-terbaik-seindonesia-berikut-daftarnya/. Bengkulu Post. Diakses pada tanggal 21 Maret 2019 pukul 20.26 WIB.

Sekaran, Uma and Roger Bougie. 2016. "Research Methods for Business: A Skill Building Approach”. Seventh Edition. United Kingdom: John Wiley \& Sons.

Shuha, Khalida. 2018. "Analisis Pengelolaan Dana Desa (Studi KAsus pada Desa-Desa selingkungan Kecamatan Lubuk Alung Kabupaten Padang Pariaman)”. Artikel. Digital Library Universitas Negeri Padang.

Sofyani, Hafiez., Rudi S., Sigit Arie W., dan Harjanti W. 2018. "Praktik Pengelolaan dan Tata Kelola Pemerintahan Desa Dlingo di Kabupaten Bantul: Pembelajaran dari Desa Percontohan". Jurnal Akuntansi Terapan Indonesia Vol. 1 No. 1 Hal. 1-16.

Sugiyono. 2016. Metode Penelitian Kuantitatif, Kualitatif, dan R\&D. Bandung: Alfabeta.

Triani, Ni Nyoman Alit dan Susi Handayani. 2018. "Praktik Pengelolaan Keuangan Dana Desa". Jurnal Akuntansi Multiparadigma Vol. 9 No. 1 Hal.136-135.

Undang-Undang Nomor 23 Tahun 2014 tentang Pemerintahan Daerah.

Undang-Undang Nomor 6 Tahun 2014 tentang Desa.

Winaya, IK., dan IPD. Dharmanu Yudharta. 2018. "Desa Membangun: Analisis Perencanaan dan Penyusunan Anggaran Pendapatan dan Belanja Desa (APBDes) Tahun 2017 (Studi Kasus di Desa Kategori Tertinggal Pada Kecamatan Kintamani Kabupaten Bangli)”. Fakultas Ilmu Sosial dan Ilmu Politik Universitas Udayana. 